\title{
Time-course effects of protein malnutrition on hepatic fatty acids $\Delta 6$ and $\Delta 5$ desaturation in the growing rat
}

\author{
BY MICHEL NARCE, JEAN-PIERRE POISSON, \\ JACQUES BELLEVILLE* AND BERNARD CHANUSSOT \\ Laboratoire de Physiologie Animale et de la Nutrition, UA CNRS 273, \\ Faculté des Sciences Mirande, BP 138, 21004 Dijon Cedex, France
}

(Received 15 January 1988 - Accepted 9 May 1988)

1. In growing rats, the time-course effects of giving a normal-protein diet ( $200 \mathrm{~g}$ casein $/ \mathrm{kg}$; NP) for $52 \mathrm{~d}$, a lowprotein diet $(20 \mathrm{~g}$ casein $/ \mathrm{kg} ; \mathrm{LP})$ for $52 \mathrm{~d}$ and a LP diet for $26 \mathrm{~d}$ followed by balanced refeeding ( $200 \mathrm{~g}$ casein/ $\mathrm{kg}$; BR) for $26 \mathrm{~d}$, on the fatty acid composition of liver total lipids and microsomal phospholipids were investigated together with $\Delta 6$ - and $\Delta 5$-microsomal desaturase activities.

2. The oleic acid content (mg/g tissue) of liver total lipids increased progressively with the LP diet, while linoleic acid was increased only at days 7 and $52.20: 3 \omega 6,20: 4 \omega 6,22: 5 \omega 6$ and $22: 6 \omega 3$ fatty acids decreased during the period on the LP diet. BR for $7 \mathrm{~d}$ was sufficient to restore the fatty acid composition of total lipids to control values. Changes in the fatty acid composition of liver microsomal $\mathrm{L}-\alpha$-phosphatidylcholines were observed only

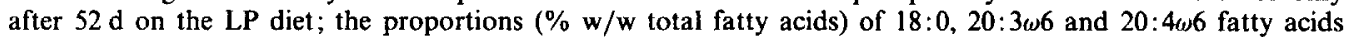
decreased while oleic acid increased. The fatty acid composition of $L-\alpha$-phosphatidylethanolamines was less affected.

3. $\Delta 6$ - and $\Delta 5$-desaturase activities decreased to $20-30 \%$ of their original values after $2 \mathrm{~d}$ on the LP diet; a smaller deficit prevailed after $14 \mathrm{~d}$ but disappeared after $25 \mathrm{~d}$, to appear again after $52 \mathrm{~d}$. As early as day 2 of BR, desaturase activities were greatly recovered and returned to control values at day 13.

4. The present work shows that modifications in microsomal $\Delta 6$ - and $\Delta 5$-desaturase activities are not strictly paralleled by the changes in the composition of fatty acids of liver total lipids and microsomal phospholipids.

Linoleic acid $(18: 2 \omega 6)$ and $\alpha$-linolenic acid $(18: 3 \omega 3)$ are the main dietary forms of essential fatty acids (EFA). In the body, especially in the liver, linoleic acid is converted mainly into arachidonic acid $(20: 4 \omega 6)$ and $\alpha$-linolenic acid into eicosapentaenoic acid $(20: 5 \omega 3)$ and docosahexaenoic acid (22:6w3). Williams \& Hurlebaus (1966) showed in the rat that a dietary protein insufficiency may lead to changes in lipid composition and suggested this to be due to an impairment of the enzyme systems converting linoleic acid into arachidonic acid. These authors found that, in rats maintained on a protein-free diet for 2 months, there

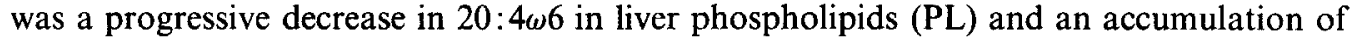

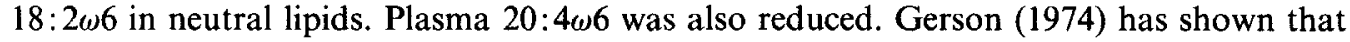

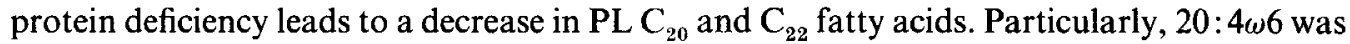
decreased in rat liver outer mitochondrial membranes and microsomes, accompanied by an accumulation of $18: 2 \omega 6$. It was postulated that $18: 2 \omega 6$ accumulation was due to impaired chain elongation or desaturation, or both, in protein-deficient rats. However, Gerson \& Wong (1978) also showed that the incubation in vitro of liver microsomes of adult rats fed on a protein-free diet for 7 weeks, with labelled palmitate or linoleate, revealed unchanged chain elongation and desaturation enzyme activities. De Gomez Dumm et al. (1970), Mercuri et al. (1979) and De Tomas et al. (1980) have shown that partial protein deprivation is associated with a decreased arachidonate:linoleate value in PL from rat liver. This was considered to be a consequence of the characterized reduction in the enzyme

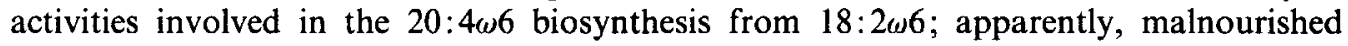
developing rats showed a decreased liver $\Delta 6$-desaturase activity which was not observed in adult rats fed on a protein-free diet for 7 weeks. These findings showed that the effect of

\footnotetext{
* For reprints.
} 
protein malnutrition on liver $\Delta 6$-desaturase activity was greater than that on $\Delta 5$-desaturase activity. $\Delta 5$-desaturase is known to be less regulated by dietary and hormonal manipulations than $\Delta 6$-desaturase (Ninno et al. 1974; Peluffo et al. 1976). Carbohydrates are known to stimulate $\Delta 9$-desaturase $(E C 1,14.99 .5)$ activity (Oshino \& Sato (1972). With a low-protein (LP) diet containing more carbohydrates than a normal-protein diet, $\Delta 9$ desaturase activity is also found to decrease, but to a lesser extent than $\Delta 6$-desaturase activity (Inkpen et al. 1969).

These previous studies, carried out on young or adult rats, gave inconsistent results due to differences related to age, and the composition of the diets and duration of feeding. There have been no reports of the effects of an LP diet on desaturase activities in growing rats. A time-course study is needed to explain these differences and to establish whether changes in desaturase activities are associated with the composition of liver fatty acids throughout the period on the diet. Thus, the present work, using weaning growing rats fed on an LP diet, then a balanced diet, investigates the relations between the activities of desaturases and the composition of fatty acids of liver lipids and microsomal PL during protein malnutrition and rehabilitation. Our findings disprove part of the hypothesis of Williams \& Hurlebaus (1966), Gerson (1974) and Gerson \& Wong (1978), and show that hepatic microsomal $\Delta 6$ - and $\Delta 5$-desaturase activities are not strictly paralleled by changes in the altered fatty acid composition of liver total lipids and microsomal phosphatidylcholines (PC) and phosphatidylethanolamines (PE).

\section{MATERIALS AND METHODS \\ Animals and diets}

Male Wistar rats (Iffa-Credo, Lyon, France), weighing 140 (SE 5) g at the beginning of the experiment, were allowed free access to a balanced control diet $(200 \mathrm{~g}$ casein $/ \mathrm{kg})$ for $10 \mathrm{~d}$ and thereafter divided into two groups. The control group (C) was fed on the balanced diet for $52 \mathrm{~d}$ whereas the experimental group (E) was divided into a further two groups; the first was fed on an LP diet ( $20 \mathrm{~g}$ casein $/ \mathrm{kg}$ ) for $26 \mathrm{~d}$, then the balanced diet (balanced refeeding; BR) for $26 \mathrm{~d}$; the second group received the LP diet for $52 \mathrm{~d}$. The compositions of the diets are shown in Table 1. Diets and water were supplied ad lib. and changed every other day. The rats were housed in stainless-steel cages at $25^{\circ}$, and light was provided for $12 \mathrm{~h}$ daily. Three group $\mathrm{E}$ and three group $\mathrm{C}$ fasted rats were killed at 08.00 hours by cervical dislocation after 2, 14, 25 and $52 \mathrm{~d}$ on the LP diet and 2, 13 and $26 \mathrm{~d}$ of BR. The livers were quickly removed, rinsed with $0 \cdot 15 \mathrm{M}$-sodium chloride and weighed. Total lipids (TL) were extracted from the livers according to Delsal's (1944) method and proteins were measured by the method of Lowry et al. (1951).

\section{Assay for in vitro desaturations}

Rat liver tissue $(3 \mathrm{~g})$ was cut into thin slices, homogenized at $4^{\circ}$ in a Potter-Elvejhem

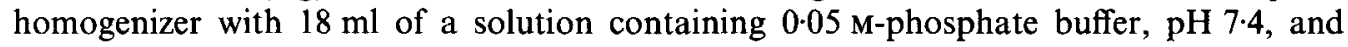
$0.25 \mathrm{M}$-sucrose and centrifuged at $8000 \mathrm{~g}$ for $30 \mathrm{~min}$. The microsomes were then isolated from the supernatant fraction by centrifugation at $105000 \mathrm{~g}$ for $60 \mathrm{~min}$ (Beckman L8-55 ultracentrifuge). The microsomal pellets were resuspended in the $0.25 \mathrm{M}$-sucrose, 0.05

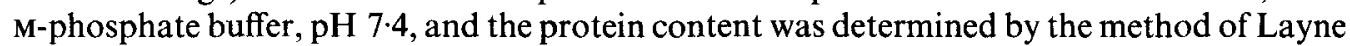
(1957).

\section{Incubation procedure}

$\left[1-{ }^{14} \mathrm{C}\right]$ linoleic acid or $\left[2-{ }^{14} \mathrm{C}\right]$ dihomo- $\gamma$-linolenic acid $(20: 3 \omega 6)(55 \mathrm{mCi} / \mathrm{mmol}$, radiochemical purity $>96 \%$, Amersham International plc, Amersham, Bucks) was diluted in ethanol to a specific activity of about $5 \mathrm{Ci} / \mathrm{mol}$ with the corresponding unlabelled pure 
Table 1. Composition of diets on a weight $(\mathrm{g} / \mathrm{kg})$ and energy $(\%)$ basis

\begin{tabular}{|c|c|c|c|c|c|c|c|c|}
\hline \multirow[b]{2}{*}{ Diet } & & \multirow{2}{*}{$\frac{\text { Protein }}{\begin{array}{c}\text { Milk } \\
\text { casein* }\end{array}}$} & \multirow{2}{*}{$\frac{\text { Fat }}{\begin{array}{c}\text { Peanut } \\
\text { oil } \dagger\end{array}}$} & \multicolumn{2}{|c|}{ Carbohydrate } & \multirow[b]{2}{*}{ Minerals§ } & \multirow[b]{2}{*}{ Vitamins $\uparrow$} & \multirow{2}{*}{$\frac{\text { Fibre* }}{\text { agar-agar }}$} \\
\hline & & & & $\begin{array}{l}\text { Maize } \\
\text { starch } \ddagger\end{array}$ & Sucrose* & & & \\
\hline Balanced & $\begin{array}{l}\text { Wt }(\mathrm{g} / \mathrm{kg}) \\
\text { Energy }(\%)\end{array}$ & $\begin{array}{l}200 \\
20 \cdot 3\end{array}$ & $\begin{array}{l}60 \\
13.7\end{array}$ & $\begin{array}{c}600 \\
60 \cdot 9\end{array}$ & $\begin{array}{l}50 \\
5 \cdot 0\end{array}$ & 20 & 20 & 50 \\
\hline Low-protein & $\begin{array}{l}\mathrm{Wt}(\mathrm{g} / \mathrm{kg}) \\
\text { Energy }(\%)\end{array}$ & $\begin{array}{l}20 \\
2 \cdot 03\end{array}$ & $\begin{array}{l}60 \\
13 \cdot 7\end{array}$ & $\begin{array}{l}780 \\
79 \cdot 2\end{array}$ & $\begin{array}{l}50 \\
5 \cdot 0\end{array}$ & 20 & 20 & 50 \\
\hline
\end{tabular}

The two diets were semi-synthetic, isoenergetic $(16845 \mathrm{~kJ} / \mathrm{kg}$ diet $)$ and were given as a powder.

* Prolabo, Paris.

$\dagger$ Peanut oil was a commercial product. Fatty acid composition of peanut oil ( $\% \mathrm{w} / \mathrm{w}$ of total): palmitic acid

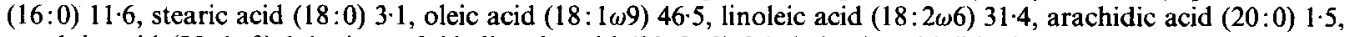
gondoic acid $(20: 1 \omega 9) 1-4$, eicosa-8,11-dienoic acid $(20: 2 \omega 9) 0 \cdot 1$, behenic acid $(22: 0) 3 \cdot 0$.

$\ddagger$ Louis François, St Maur.

$\S$ UAR $205 \mathrm{~B}$, Epinay sur Orge. The salt mix provided the following ( $\mathrm{mg} / \mathrm{kg} \mathrm{diet}$ ): calcium 3000 , phosphorus 2100 , potassium 1830 , chloride 1200 , sodium 900 , magnesium 214 , manganese 40 , zinc 12 , copper $4 \cdot 5$, cobalt $0 \cdot 32$, iodine 0.9 , iron 105 .

T The UAR 200 vitamin mixture provided the following $(\mathrm{mg} / \mathrm{kg} \mathrm{diet})$ :retinol $51 \cdot 6$, cholecalciferol 1 , thiamin 150 , riboflavin 200 , pyridoxin 70 , cyanocobalamin 0.2 , calcium pantothenate 250 , nicotinic acid 800 , pteroylmonoglutamic acid 20, vitamin E 500, menadione 30, choline 175.

fatty acid (Sigma, St Louis, Mo, USA). The assay conditions were as follows: $5 \mathrm{mg}$ microsomal proteins were incubated in an open Erlenmeyer flask with $20 \mathrm{nmol}$ diluted labelled fatty acid, in a Salvis shaker (Bioblock Scientific, Strasbourg) at $37^{\circ}$ for $5 \mathrm{~min}$ in

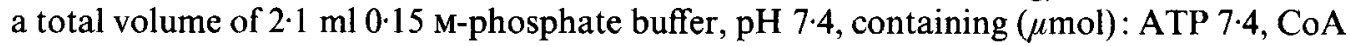
1, NADPH 2·5, magnesium chloride 10 . Under such conditions, the formation of product was proportional to the time of incubation and protein concentration. Saturating substrate concentration was reached near $40 \mathrm{nmol} /$ incubation (Ratieuville, 1985). Incubations were stopped by adding $5 \mathrm{ml}$ alcoholic potassium hydroxide $(120 \mathrm{~g} / \mathrm{l})$, saponified for $1 \mathrm{~h}$ at $75^{\circ}$, then methylated according to Slover \& Lanza (1979). The conversion of $\left[{ }^{14} \mathrm{C}\right]$ linoleic acid to $\left[{ }^{14} \mathrm{C}\right]-\gamma$-linolenic acid $(18: 3 \omega 6)\left(\Delta 6\right.$ desaturation) and $\left[{ }^{14} \mathrm{C}\right]$ dihomo- $\gamma$-linolenic acid to $\left[{ }^{14} \mathrm{C}\right]$ arachidonic acid ( $\Delta 5$ desaturation) was measured by radiogas-liquid chromatography using a Packard model 470 gas-liquid chromatograph (glass column packed with $24 \%$ DEGS in chromosorb W) according to Bezard et al. (1964).

\section{Lipid analysis}

The rate of liver neutral lipid formation was obtained from the difference between TL (evaluated gravimetrically) and PL. The total PL were assayed for phosphorus by the method of Bartlett (1959). This PL-P content was multiplied by 25 to estimate the amount of PL. Liver water content was evaluated by lyopholization in an RP2V SERAIL lyophilizator. Microsomal PC and PE were isolated by thin-layer chromatography according to Wagner et al. (1961). After saponification and methylation, as described previously, the fatty acid composition of the liver TL and liver microsomal PC and PE were measured by gas-liquid chromatography (Packard model 419 gas-liquid chromatograph equipped with a flameionization detector and $30 \mathrm{~m}$ capillary glass column packed with Carbowax $20 \mathrm{M}$ ).

\section{Statistics}

Results are expressed as the arithmetical means of each group with their standard errors. Statistical significance of differences between means was determined by Student's $t$ test. 


\section{RESULTS}

Group $\mathrm{C}$ showed a normal body-weight increase (Table 2). Group E rats weighed 56 and $40 \%$ of that of group C rats after 25 and $52 \mathrm{~d}$ respectively on the LP diet. Soon after the start of BR, the weight of group $\mathrm{E}$ rats increased rapidly, reaching $80 \%$ of the group $\mathrm{C}$ body-weight after $26 \mathrm{~d}$.

The food intake with the LP diet was 79 and $69 \mathrm{~g} / \mathrm{kg}$ body-weight per $\mathrm{d}$ in groups $\mathrm{C}$ and $E$ respectively. At the beginning of $B R$ the consumption of group $E$ was approximately twice that of group C.

The liver weight: body-weight value for group E decreased only after $2 \mathrm{~d}$ on the LP diet, while the liver protein content showed a decrease at every measurement. Conversely, liver protein was $31 \%$ higher at day 2 of BR, suggesting a rebound effect which persisted after $13 \mathrm{~d}$ of BR. At the end of BR similar values were observed for groups $\mathrm{E}$ and $\mathrm{C}$. Group $\mathrm{E}$ also showed a progressive increase in the liver TL content of 36,54 and $148 \%$ after 14, 25 and $52 \mathrm{~d}$ respectively on the LP diet (Table 2). This increase was essentially due to the neutral lipids, with an $85 \%$ increase in triacylglycerols in the malnourished rats. After $2 \mathrm{~d}$ of BR there was still an overload of neutral lipids in the refed rats, which disappeared after $13 \mathrm{~d}$. The PL levels were not significantly modified with the LP diet and BR. The liver water content (approximately $700 \mathrm{~g} / \mathrm{kg}$ ) was stable during feeding the LP diet and BR. No hepatic oedema was thus observed in spite of the significance and duration of the protein malnutrition.

Fig. 1 shows the fatty acid composition (mg/g) tissue) of the liver TL of rats at different time-intervals. The 16:0 level was higher than that of the control group on the LP diet. 18:1 $\omega 9$ increased progressively, being 6.5 times higher in group $E$ than in group $C$ after $52 \mathrm{~d}$ on the LP diet. Compared with group C, the content of $18: 2 \omega 6$ was greater on the LP diet, and was 4-4-fold greater at $52 \mathrm{~d}$. In contrast, $20: 3 \omega 6$ decreased ; 20:4 46 decreased also with the LP diet and was 0.6 of the control value after $52 \mathrm{~d}$. During protein malnutrition, because of the fall in the amount of $20: 4 \omega 6$ and the increase in $18: 2 \omega 6$, the $20: 4 \omega 6 / 18: 2 \omega 6$ value decreased considerably: 2- and 10-fold after 7 and $52 \mathrm{~d}$ on the LP diet respectively.

After $3 \mathrm{~d}$ on the BR diet, liver 16:0 and 18:1 $\omega 9$ levels remained higher in group $E$ than in group $C$, but the difference between the two groups was less marked than that on the LP

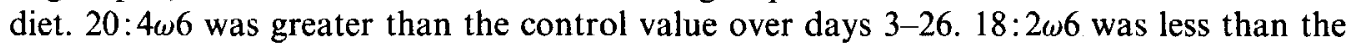
control value at day 3 but steadily increased and exceeded the control value by day 26 . At this time the amounts of 16:0 and 16:1 $1 \omega 7$ were lower in group $E$ than in group $C$. Therefore $26 \mathrm{~d}$ of BR was not sufficient to normalize the fatty acid composition of TL.

Table 3 shows the fatty acid composition (\% w/w total fatty acids) of liver microsomal PC after 14, 25 and $52 \mathrm{~d}$ on the LP diet and 13 and $26 \mathrm{~d}$ of BR. Significant changes were

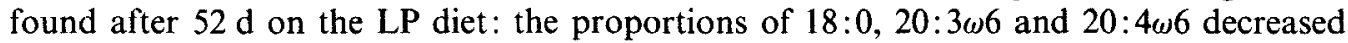
significantly while the proportion of $18: 1 \omega 9$ increased. Other fatty acids were unchanged. The 20:4 $\omega 6 / 18: 2 \omega 6$ value, which had increased after $14 \mathrm{~d}$ on the LP diet, fell after $25 \mathrm{~d}$, being half the control value after $52 \mathrm{~d}$. After $26 \mathrm{~d}$ of $\mathrm{BR}$ the values were similar in both groups.

Table 4 shows that the 18:0 content of liver microsomal PE decreased after $52 \mathrm{~d}$ on the LP diet in spite of a transitory increase after $14 \mathrm{~d}$. The proportions of $18: 1 \omega 9$ and $18: 2 \omega 6$ increased by 2- and 2.7-fold respectively after $52 \mathrm{~d}$ on the LP diet in spite of a transitory decrease after $14 \mathrm{~d}$ on the LP diet. The proportion of $20: 4 \omega 6$ decreased 2 -fold after $25 \mathrm{~d}$ on the LP diet and was similar to the control value after $52 \mathrm{~d}$. The $20: 4 \omega 6 / 18: 2 \omega 6$ value was 3.8-fold and 2-fold lower than control values after 25 and $52 \mathrm{~d}$ respectively on the LP diet. By day 26 of BR the values for this ratio and the PE fatty acid composition were similar for the two groups. 

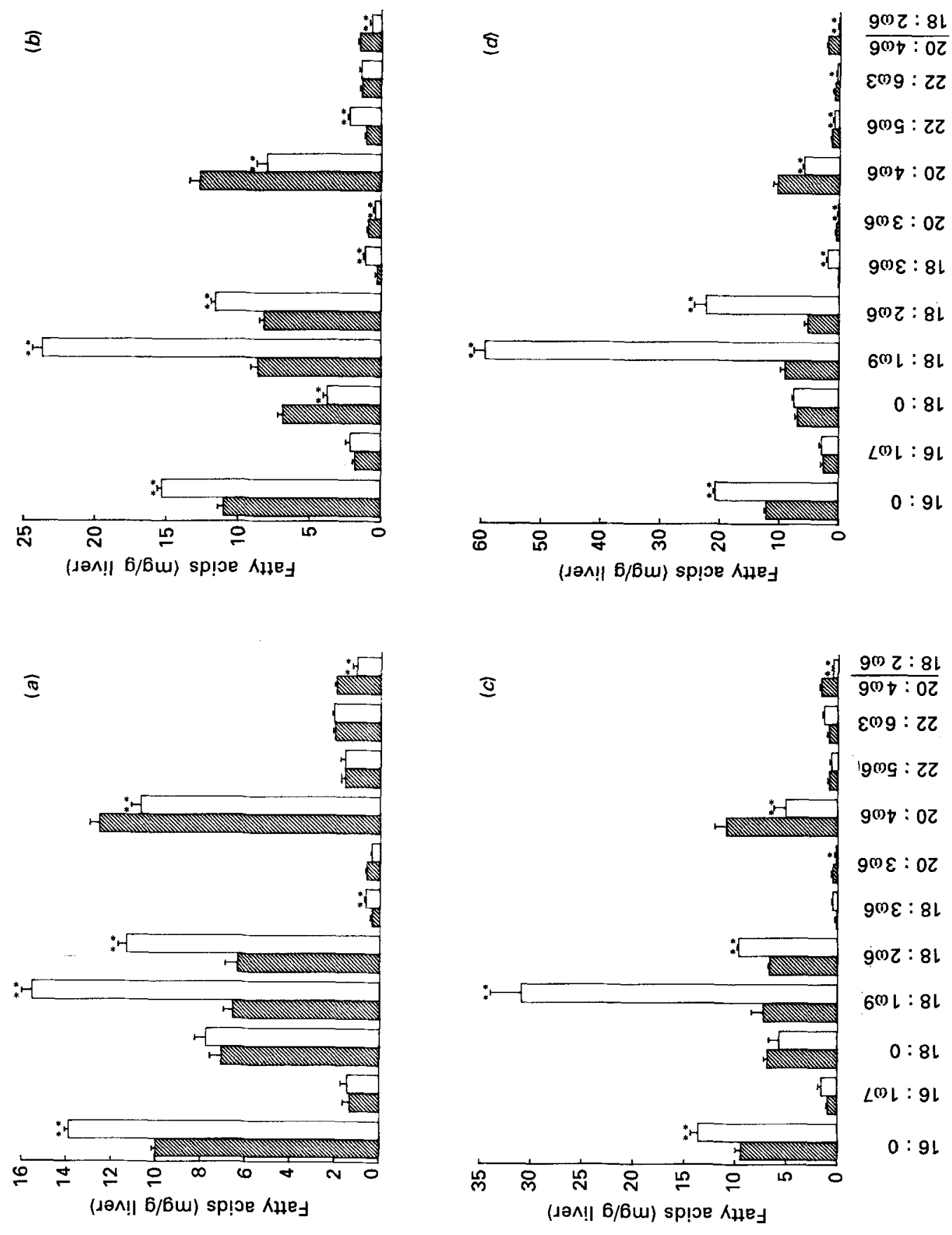

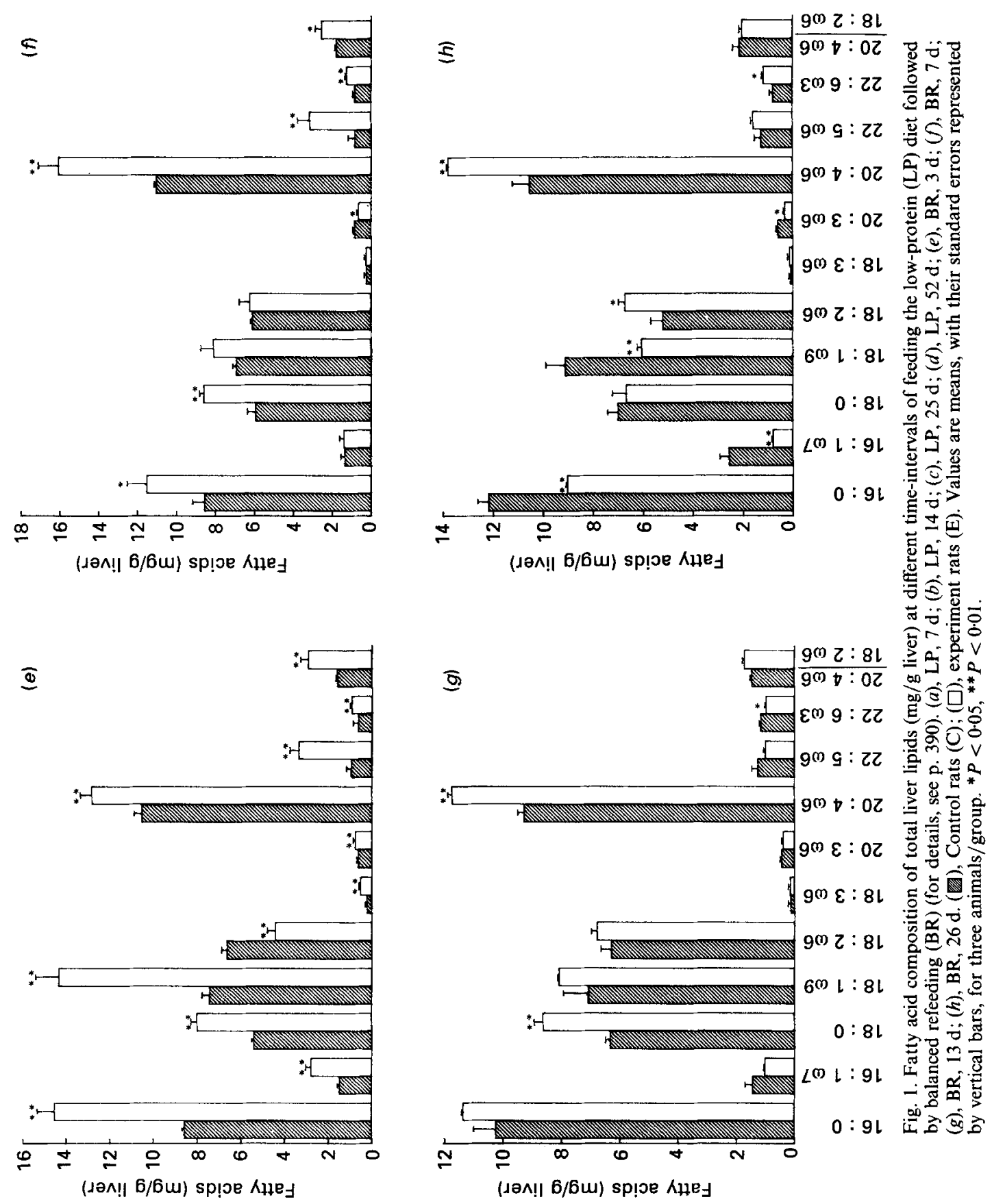


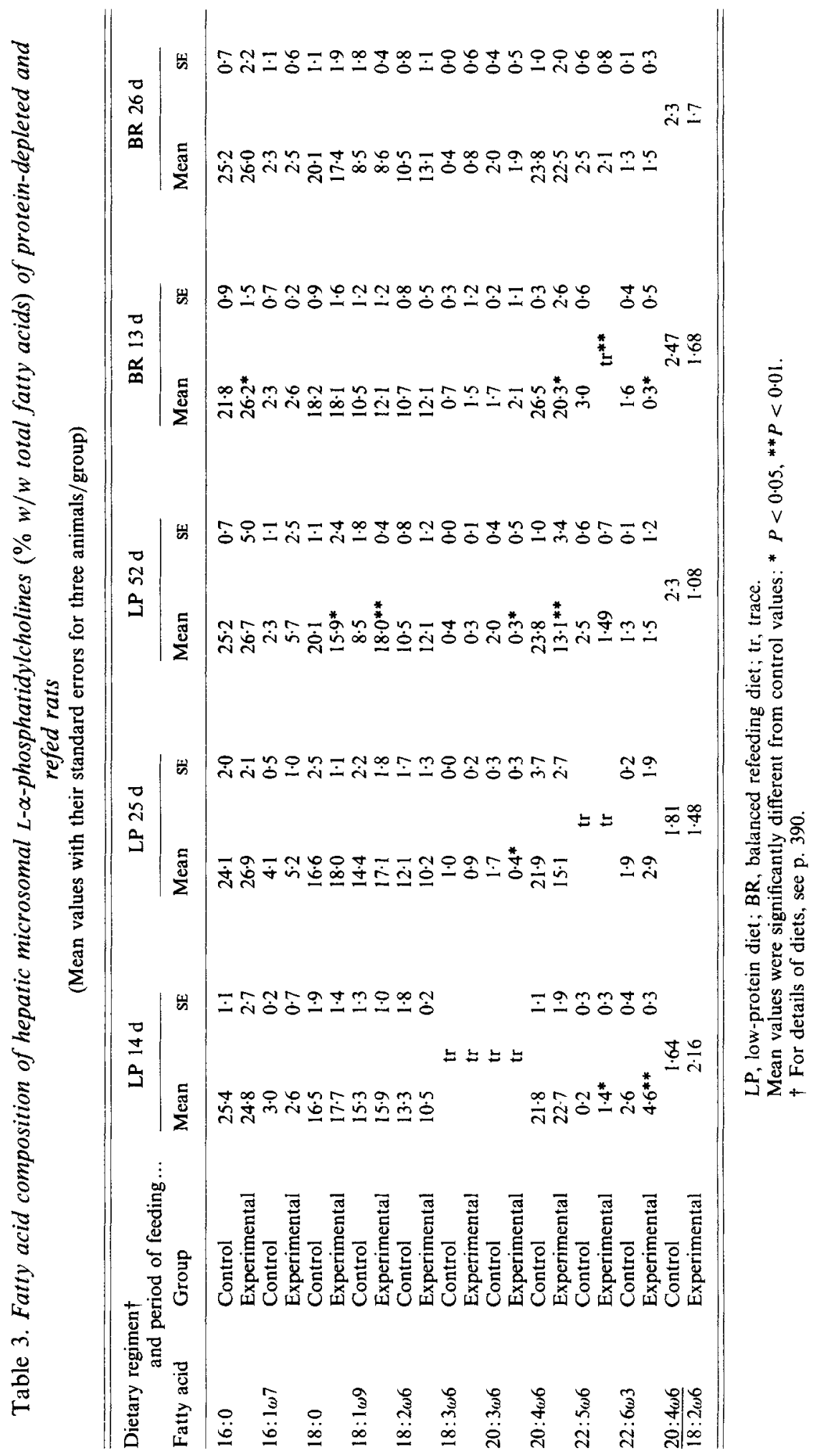


Desaturase activities and protein malnutrition

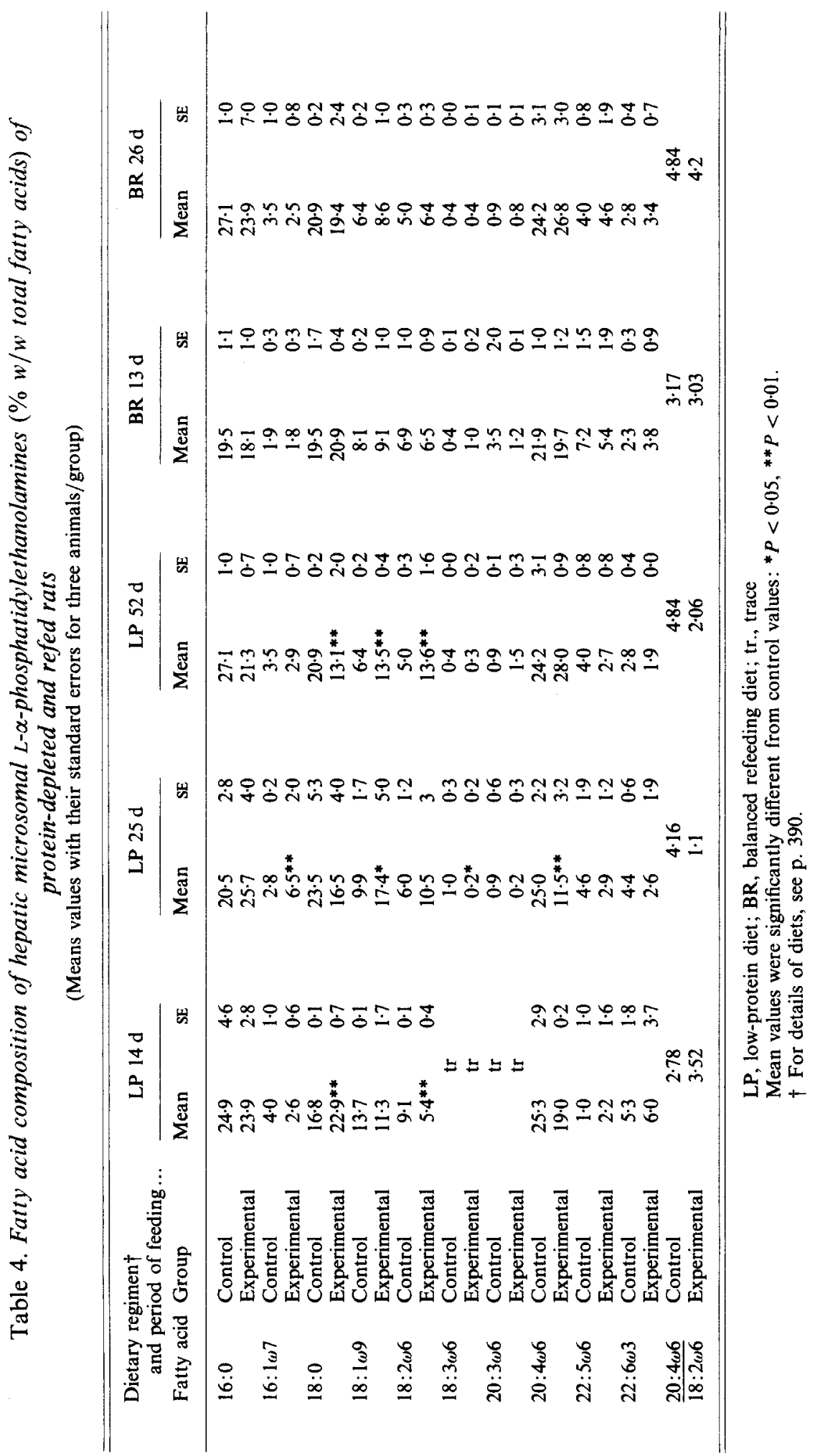




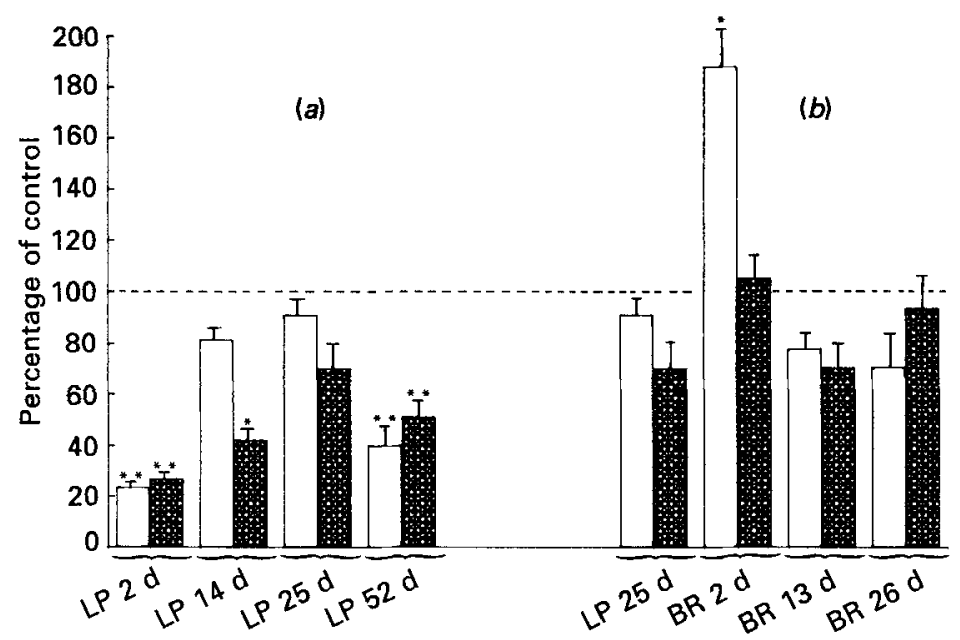

Fig. 2. $\Delta 6$ - and $\Delta 5$-microsomal desaturase activities of experimental groups ( $\%$ of control values). ( $\square$ ), $\Delta 6$-desaturase activities (labelled substrate: $18: 2 \omega 6,40 \mathrm{nmol}$ ); (䍹), $\Delta 5$-desaturase activities (labelled substrate: $20: 3 \omega 6,40 \mathrm{nmol}$ ). (a) Rats fed on a low-protein (LP) diet; $(b)$ rats fed on an LP diet for $25 \mathrm{~d}$ followed by balanced refeeding (BR). For details of dietary regimens, see p. $390 .{ }^{*} P<0 \cdot 05,{ }^{* *} P<0 \cdot 01$.

Fig. 2 shows the activities of $\Delta 6$ - and $\Delta 5$-microsomal desaturases as percentages of control values, each control value being 100 . Control values varied according to the age of the animals (pmol/mg protein per min): 90.6 (SE 46) for $\Delta 6$-desaturation and 388.0 (SE 73) for $\Delta 5$-desaturation. The activities of the two desaturases were $20-30 \%$ of control values after $2 \mathrm{~d}$ on the LP diet. The $\Delta 6$-desaturase activity reached 81 and $91 \%$ of control values on days 14 and 25 respectively. For this time-interval the activity of $\Delta 5$-desaturase showed a more marked decrease than that of $\Delta 6$-desaturase : $42 \%$ of the control value at $14 \mathrm{~d}, 70 \%$ at $25 \mathrm{~d}$. At $52 \mathrm{~d}$ on the LP diet, there was a significant decrease in the activities of both desaturases : 40 and $51 \%$ of control values for $\Delta 6$ - and $\Delta 5$-desaturase activities respectively.

As early as day 2 of $B R$ the $\Delta 6$ - and $\Delta 5$-desaturase activities reached about 180 and $100 \%$ of control values respectively. From day 26 of BR the differences between the two groups in the activities of the two desaturases were not significant.

\section{DISCUSSION}

The rate of food intake ( $\mathrm{g} / \mathrm{kg}$ body-weight per $\mathrm{d}$ ) was similar for the two groups of animals. The low-protein content of the deficient diet allows the assertion that group $\mathrm{E}$ suffered from protein malnutrition and not from protein-energy malnutrition. The immediate growth retardation of the malnourished rats proved to be a more sensitive indicator of their protein status than the measurement of tissue protein concentration. The percentage decrease in weight was the same for the liver and the whole body, except at the beginning of feeding the LP diet when the liver was more sensitive to the LP diet and there was a 25-35\% decrease in the liver protein content. This decrease was an adaptive response to the protein depletion: under these conditions the protein needs of the lean body mass diminished. Anthony \& Edozien (1975) have shown that total liver DNA, RNA and protein fall in rats fed on LP diets; thus the hepatic protein synthesis is disturbed.

Liver steatosis, with an increase in triacylglycerol and its rapid disappearance following BR, was a specific indicator of protein depletion. An impaired transport of triacylglycerol by very-low-density-lipoproteins (VLDL) from the fatty liver may be responsible for the lipid accumulation in the liver of rats fed on an LP diet, and the low level of VLDL may 
be due to a reduction in the biosynthesis of VLDL apolipoproteins as suggested by Truswell et al. (1969), Flores et al. (1970), Seakins \& Waterlow (1972) and proved by Yagasaki \& Kametaka (1978) and Meghelli-Bouchenak et al. (1987).

In contrast the PL content was not modified. However, in the studies of Williams \& Hurlebaus $(1965 a, b)$, liver PL decreased during total protein depletion. This finding is not inconsistent with our findings because several different biological and biochemical modifications have been found to be associated with diets containing $0-20 \mathrm{~g}$ protein $/ \mathrm{kg}$ (Anthony \& Edozien, 1975).

In liver TL, amounts of some fatty acids were modified by the LP diet: $20: 3 \omega 6$ and 20:4 46 decreased while $18: 1 \omega 9,18: 2 \omega 6$ and $18: 3 \omega 6$ increased. This suggests that the LP diet led to an increase in the formation of $18: 1 \omega 9$ by $\Delta 9$-desaturation and a reduction in the conversion of $18: 2 \omega 6$ to $20: 4 \omega 6$ by $\Delta 6$ - then $\Delta 5$-desaturation; the same hypothesis was also suggested by Naismith (1973), Holman et al. (1981) and Leat (1983), based on their findings relating to hepatic fatty acid compositions. These changes in liver TL could also be due to disturbances caused by protein depletion in other enzyme systems implicated in the metabolism of fatty acids, e.g. incorporation, fatty acid synthetase, acyl-CoA synthetases, mitochondrial $\beta$-hydroxybutyrate dehydrogenase (indirectly implicated) (Gerson \& Wong, 1978). The export of fatty acids from the liver is also altered (Truswell et al. 1969; Seakins \& Waterlow, 1972; Yagasaki \& Kametaka, 1978; Meghelli-Bouchenak et al. 1987).

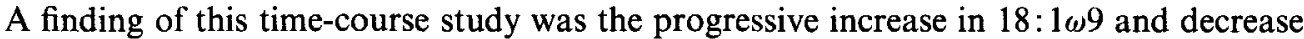
in $20: 4 \omega 6$ up to day 25 on the LP diet. Then, $52 \mathrm{~d}$ of protein depletion markedly increased 18: $1 \omega 9$ and $18: 2 \omega 6$, while $20: 4 \omega 6$ was unchanged from the $25 \mathrm{~d}$ value.

Another finding was that after $3 \mathrm{~d}$ on the BR diet, $18: 2 \omega 6$ decreased and $20: 4 \omega 6$ exceeded control amounts. 18:1 $\omega 9$ levels remained high on BR but values were lower than those with the LP diet. After $26 \mathrm{~d}$ BR, there were still considerable differences between the two groups which were statistically significant in respect of several fatty acids.

On the LP diet, $14 \mathrm{~d}$ seemed to be insufficient to observe changes in the composition of both microsomal PC and PE. In these fractions, the proportions of $20: 3 \omega 6$ at 25 and $52 \mathrm{~d}$, and the proportion of $20: 4 \omega 6$ at $52 \mathrm{~d}$ reflect a possible depletion of $\Delta 6$ - and $\Delta 5$-desaturase activities. In PE, the proportions of $20: 4 \omega 6$ and $18: 2 \omega 6$ at 25 and $52 \mathrm{~d}$ respectively reflect a similar depletion. At $52 \mathrm{~d}$, the effects of protein depletion were apparently different for

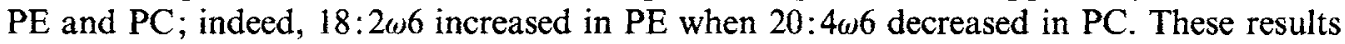
are similar to those of Rogers (1972) for PE, but not for PC. Therefore, all changes found in microsomal PC and PE from day 25 on the LP diet support the suggested changes in $\triangle 6$ and $\Delta 5$-desaturase activities.

In LP-fed animals, proportions of 18:0 and 18:1 $\omega 9$ in liver PC decreased and increased respectively compared with controls at day 52 . In liver PE, 18:0 decreased at day 52 and 18: $1 \omega 9$ increased at both days 25 and 52 . Harada et al. (1969) using rat liver mitochondria and Rogers (1971) using rat liver microsomes found similar changes with an LP diet. This may be due, in part, to an increase in $\Delta 9$-desaturase activity, this enzyme being affected differently by diet than the other desaturases (Inkpen et al. 1969).

After $26 \mathrm{~d}$ on the BR diet, the fatty acid composition of microsomal PL was almost normal.

These changes in long-chain unsaturated fatty acid composition may have a significant effect on the functions of membranes (Gerson \& Wong, 1978). Reduced intracellular CoA during protein deficiency (Gerson \& Wong, 1978) may explain modifications in the proportions of fatty acids derived from the liver acetyl CoA pool, resulting from a lower concentration of CoA as a cofactor involved in fatty acid synthesis, oxidation, elongation and desaturation.

Linoleic acid, which is desaturated and elongated by microsomal enzymes to $20: 4 \omega 6$, 
may be accumulated owing to impairment of chain elongation or desaturation, or both, in protein-deficient rats. Our results showed that $2 \mathrm{~d}$ on the LP diet were sufficient to induce a decrease in $\Delta 6$ - and $\Delta 5$-desaturase activities.

The literature is apparently inconsistent with regard to the effects of an LP diet on rat desaturase activities. Changes were not found in adult rats fed on an LP diet for 7 weeks (Gerson \& Wong, 1978). Low $\Delta 6$ - and $\Delta 5$-desaturase activities have been reported in pregnant (Mercuri et al. 1979) and early developing (10 d after wearning) rats (De Tomas et al. 1980) fed on an LP diet. Out findings clearly demonstrate that protein depletion has immediate effects on $\Delta 6$ - and $\Delta 5$-desaturase activities. Whereas De Tomas et al. (1980) showed the effect of an LP diet on pups from dams nourished under such conditions until weaning, we have shown in the present study the effect of protein depletion on young rats. It seems that it is only when protein requirements are important (as during growth or pregnancy) that protein depletion reduces the activities of $\Delta 6$ - and $\Delta 5$-desaturases. This might explain the observations of Gerson \& Wong (1978) in adult rats.

There was a pronounced decrease in the activities of the desaturases as early as $2 \mathrm{~d}$ on the LP diet (Fig. 2). After 14 and $25 \mathrm{~d}$ of LP they appeared to increase somewhat but were still below the control value. After $52 \mathrm{~d}$ of LP there was a return to significantly lower values. This time-course study demonstrates that adaptive changes take place during longterm protein depletion: this may be due to the fact that, at the beginning of giving the LP diet, the pool of circulating amino acids decreased markedly and the enzymes with rapid turnover were immediately affected. As the animals adapted to the LP diet, their growth was retarded and protein catabolism and amino acid availability increased; desaturase rates remained relatively high.

After $52 \mathrm{~d}$ on the LP diet, the adaptive capacity is exceeded, particularly as far as the endogenous proteins are concerned and the enzyme contents are reduced, as suggested by Waterlow et al. (1960). Under these conditions, the enzyme proteins : total proteins ratio of microsomal proteins may decrease.

Hormonal regulation of these desaturase activities may also be implicated. Insulin, thyroxin and corticosterone are known to regulate desaturase activities (Faas et al. 1977; Brenner, 1981; Poisson, 1985). Furthermore, protein deficiency leads to a significant decrease in serum insulin, thyroxin and corticosterone levels (Anthony \& Edozien, 1975). Faas et al. (1977) have shown that thyroxin stimulation of in vitro microsomal fatty acid desaturation may be affected by the inhibition of non-desaturase oxygen-utilizing reactions. But important contradictions remain about the effect of protein deficiency on the serum level of thyroid hormones, some authors showing no significant changes (Graham et al. 1973; Rastogi et al. 1974; Tulpo et al. 1979). Poisson (1985), in relation to diabetes, reported that a low level of insulin in plasma may induce a partial inhibition of $\Delta 6$ - and $\Delta 5$ desaturase activities. We may speculate that if the secretion of these hormones, or the sensitivity of desaturases to them, varied during the time-period on the LP diet, the $\Delta 6$ - and $\Delta 5$-desaturase activities were not regularly modified and, therefore, may in part explain our results. The marked recovery at day 2 during $B R$ indicated that the changes induced by protein depletion are immediately reversible by balanced refeeding. However, the findings after $14 \mathrm{~d}$ suggested that this recovery is not stable, and $26 \mathrm{~d}$ were not sufficient to restore completely the activities of desaturases.

The results of the present study showed that there is no simple relation between the changes in desaturase activities and fatty acid composition, since changes in desaturase activities, particularly adaptive changes, were not immediately reflected by modifications in fatty acid compositions. On the other hand, the fatty acid compositions of microsomal PE and PC and of total liver lipids in vivo are not only under the influence of desaturases: protein depletion is known to affect the metabolism of liver fatty acids as discussed 
previously. However desaturase activities in vivo are related to substrate availability, and removal of the product of desaturation is influenced by protein depletion.

In conclusion, the present study, based on young growing rats and on the time-course of LP feeding followed by BR, demonstrates that protein depletion immediately reduces $\Delta 6$ and $\Delta 5$-desaturase activities of young rats, but in the long-term adaptive changes may occur. Modifications in the relative amounts of $18: 2 \omega 6,18: 3 \omega 6,20: 3 \omega 6$ and $20: 4 \omega 6$ in liver total lipids and microsomal PE and PC induced by the diet are not strictly related to the reduced $\Delta 6-$ and $\Delta 5$-desaturase activities : the conversion of $18: 2 \omega 6$ to $20: 4 \omega 6$ could also depend on other interacting factors, e.g. elongation, oxidation, substrate availability, removal of product, hormone status. BR results in an immediate change in metabolic state and hepatic desaturase activities are markedly increased, but this effect is not maintained.

Because $\Delta 9$-desaturation is not always affected as much as $\Delta 6$ - and $\Delta 5$-desaturation by changes in the composition of the diet (Inkpen et al. 1969), and because variations in the amounts of 18:1 $\omega 9$ in liver TL and microsomal PE and PC suggest an increase of $\Delta 9$ desaturase activity, it appears necessary to investigate the activity of this enzyme during protein depletion. The adaptive changes in desaturase activities observed in the present work suggest that the lack of effect of protein depletion on desaturases observed by Gerson \& Wong (1978) in adult rats may be explained by an adaptation of animals to the diet: this hypothesis remains to be confirmed by studying the effects of short-term protein depletion in adult rats.

The authors thank Mrs Marie-Thérèse Divry-Aellen for her expert technical assistance, Dr Tor-Arne Hagve (Rikshospitalet, Oslo, Norway) for helpful suggestions, and Colin Straker and Anne Magnet for correcting the English. This work was supported by Research Grants $83 \mathrm{~L} 115901$ and $84 \mathrm{~L} 069201$ from Ministère de la Recherche et de l'Industrie (Health and development program) and by Ministère de l'Education Nationale. Part of this work was presented as a Poster at the XIII International Congress of Nutrition, Brighton, August 1985.

\section{REFERENCES}

Anthony, L. E. \& Edozien, J. C. (1975). Journal of Nutrition 105, 631-648.

Bartlett, G. R. (1959). Journal of Biological Chemistry 234, 466-468.

Bezard, J., Boucrot, P. \& Clement, G. (1964). Journal of Chromatography 14, 368-377.

Brenner, R. R. (1981). Progress in Lipids Research 20, $41-47$.

De Gomez Dumm, I. N. T., De Alaniz, M. J. T. \& Brenner, R. R. (1970). Journal of Lipid Research 11, 96-101.

Delsal, J. L. (1944). Bulletin de la Société de Chimie Biologie 29, 99-105.

De Tomas, M. E., Mercuri, O. \& Rodrigo, A. (1980). Journal of Nutrition 110, 595-599.

Faas, F. H., Carter, W. J. \& Wynn, J. O. (1977). Archives of Biochemistry and Biophysics 182, 71-81.

Flores, H., Sierralta, W. \& Monckeberg, F. (1970). Journal of Nutrition 100, 375-379.

Gerson, T. (1974). Journal of Nutrition 104, 701-709.

Gerson, T. \& Wong, H. N. (1978). Lipids 13, 446450.

Graham, G. G., Baertl, J. M., Claeyssen, G., Soskind, R., Greenberg, A. H., Thompson, R. G. \& Blizzard, R. M. (1973). Journal of Pediatrics 83, 321-331.

Harada, N., Kurahashi, M. \& Haga, M. (1969). Agricultural and Biological Chemistry 33, 168-175.

Holman, R. T., Johnson, S. B., Mercuri, O., Itarte, H. J., Rodrigo, M. A. \& De Tomas, M. E. (1981) American Journal of Clinical Nutrition 34, 1534-1539.

Inkpen, C. A., Harris, R. A. \& Quackenbush, W. F. (1969). Journal of Lipid Research 10, 277-282.

Layne, E. (1957). Spectrophotometric and Turbidimetric Methods for Measuring Proteins. New York: Academic Press.

Leat, W. M. F. (1983). Proceedings of the Nutrition Society 42, 333-343.

Lowry, O. H., Rosenbrough, W. J., Farr, A. L. \& Randall, R. J. (1951). Journal of Biological Chemistry 193, 265-275.

Meghelli-Bouchenak, M., Boquillon, M. \& Belleville, J. (1987). Journal of Nutrition 117, 641-649.

Mercuri, O., De Tomas, M. E., \& Itarte, H. (1979). Lipids 14, 822-825. 
Naismith, D. L. (1973). British Journal of Nutrition 30, 567-576.

Ninno, R. E., De Torrengo, M. A. P., Castuma, J. C. \& Brenner, R. R. (1974). Biochimica et Biophysica Acta 360, 124-133.

Oshino, N. \& Sato, R. (1972). Archives of Biochemistry and Biophysics 149, 369-377.

Peluffo, R. O., Nervi, A. M. \& Brenner, R. R. (1976). Biochimica et Biophysica Acta 441, $25-31$.

Poisson, J.-P. (1985). Enzyme 34, 1-14.

Rastogi, G. K., Sawhney, R. C., Panda, N. C. \& Tripathy, B. B. (1974). Hormone and Metabolic Research 6, 528-529.

Ratieuville, P. (1985). Contribution à l'étude de la $\Delta 5$ désaturation in vitro de l'acide dihomo- $\gamma$-linolénique $(\mathrm{C} 20: 3 n-6)$ par les microsomes hépatiques de rats. Effets des acides gras alimentaires. Troisième Cycle Thesis, University of Dijon, France.

Rogers, C. G. (1971). Journal of Nutrition 101, 1547-1554.

Rogers, C. G. (1972). Nutrition Reports International 5, 381-390.

Seakins, A. \& Waterlow, J. C. (1972). Biochemical Journal 129, 793-795.

Slover, H. T. \& Lanza, E. (1979). Journal of the American Oil Chemists Society 56, 933-943.

Truswell, A. S., Hansen, J D., Watson, C. E. \& Wannenburg, P. (1969). American Journal of Clinical Nutrition 22, $568-576$.

Tulpo, L., Krupp, P. P., Danforthe, E. Jr \& Horton, E. S. (1979). Journal of Nutrition 109, 1321-1332.

Wagner, H., Hörhammer, L. \& Wolf,, P. (1961). Biochemische Zeitschrift 334, 175-184.

Waterlow, J. C., Cravioto, J. \& Stephen, J. M. L. (1960). Advances in Protein Chemistry, vol. 15, pp. 131-227. New York: Academic Press.

Williams, J. N. \& Hurlebaus, A. J. (1965a). Journal of Nutrition 85, $73-81$.

Williams, J. N. \& Hurlebaus, A. J. (1965 b). Journal of Nutrition 85, 82-88.

Williams, J. N. \& Hurlebaus, A. J. (1966). Journal of Nutrition 89, 477-486.

Yagasaki, K. \& Kametaka, M. (1978). Journal of Nutritional Science and Vitaminology 24, 149-156. 